\title{
Changes in Morphology, Infectivity and Haemagglutinating Activity of Semliki Forest Virus Produced by the Treatment with Caseinase $\mathbf{C}$ from Streptomyces albus $\mathbf{G}$.
}

\author{
By P. M. OSTERRIETH AND CLAIRE M. CALBERG-BACQ \\ Laboratoires de Microbiologie Générale et Médicale, Université de Liège, Belgium
}

(Received 2 July 1965)

\begin{abstract}
SUMMARY
Electron micrographs of negatively stained Semliki Forest virus were made before and after treatment of the virus with caseinase $\mathrm{C}$ from Streptomyces albus $\mathrm{G}$. The virus appeared as roughly spherical (diameter $550-590 \AA$ ), covered with projections and sometimes bearing an appendix, which seemed to be a fold of the envelope. Treated with caseinase $\mathrm{C}$ in tris buffered saline, the virus lost its projections and its haemagglutinating activity but remained infectious. The site of haemagglutination, then, is probably located on the projections. Treated with caseinase $\mathrm{C}$ in phosphate buffer, the virus lost its infectivity as well as its haemagglutinating activity; the number of the remaining viral particles was not significantly modified. These structures had no projections; their envelope was degraded and sometimes completely destroyed. In this case, they had a smaller diameter $(385-890 \AA)$ than the projectionless particles obtained by treatment in tris buffered saline (410-460 A). As the virus particles with degraded envelope still contained as much infectious RNA as the controls, it was thought that some degree of integrity of the envelope was necessary for the particle infectivity. Thus the site for infectivity appeared to be different from that for haemagglutination.
\end{abstract}

\section{INTRODUCTION}

Caseinase C, an enzyme produced by Streptomyces albus G, destroys the infectivity of lipoprotein-containing viruses such as Semliki Forest virus and influenza virus (Osterrieth \& Dierickx, 1965; Reginster, 1965a). Influenza virus possesses, around its nucleoprotein, an envelope covered with spikes (Horne \& Wildy, 1963). Sindbis virus, which is closely related to Semliki Forest virus, also possesses an envelope with projections (Mussgay \& Rott, 1964). In both cases, the envelope is responsible for haemagglutination. Trypsin treatment of some strains of influenza virus cuts off the spikes and destroys the haemagglutinating activity (Borecky, Lackovic \& Mrena, 1964). Caseinase $\mathrm{C}$ treatment at low ionic strength leads to similar results (Reginster, 1965b).

Semliki Forest virus treated with caseinase $\mathrm{C}$ loses its ability to agglutinate red blood cells (Osterrieth, $1965 a, b$ ). We have now treated Semliki Forest virus with caseinase $\mathrm{C}$ under two sets of conditions and have tried to correlate the observed modifications of the biological properties of the virus with changes in the morphology of the virus particles. 


\section{METHODS}

Solutions. BBS = borate-buffered saline of Clarke \& Casals (1958). TBS = trisbuffered saline $(0.15 \mathrm{M}-\mathrm{NaCl}+0.05 \mathrm{M}$-tris $+0.005 \mathrm{~N}-\mathrm{HCl})$ containing $0.1 \%(\mathrm{w} / \mathrm{v})$ bovine plasma albumin (Armour fraction V). GBSS = tris Gey's solution of Porterfield (1960) to which $0 \cdot 1 \%(\mathrm{w} / \mathrm{v})$ bovine plasma albumin was added. PB = phosphate buffer (0.00284 $\mathrm{M}-\mathrm{Na}_{2} \mathrm{HPO}_{4}+0.0016 \mathrm{M}-\mathrm{NaH}_{2} \mathrm{PO}_{4} ; \mathrm{pH} \mathrm{7 \cdot 0)}$.

Growth medium for chick embryo cells: Porterfield (1960) tris growth medium in which the concentration of calf serum was increased to $20 \%(\mathrm{v} / \mathrm{v})$ and the chick embryo extract omitted.

Agar overlay medium: Porterfield (1960) tris overlay medium in which the final concentration of chick embryo extract was increased to $7.5 \%(v / v)$, and the neutral red omitted.

Purified virus suspension. Our purification procedure is a modification of that of Cheng (1961). Two-day mice were inoculated intracerebrally with about 1000 plaqueforming units (p.f.u.) of Semliki Forest virus suspended in GBSS. After 24 hr, when some mice were dying, the brains were harvested and homogenized in BBS (pH 9.0). The suspension was clarified by centrifugation at $3000 \boldsymbol{g}$ for $\mathbf{3 0} \mathrm{min}$. After addition of protamine sulphate $(5 \mathrm{mg} . / \mathrm{ml}$.), the supernatant fluid was stored overnight at $4^{\circ}$. The next morning the suspension was again clarified by centrifugation at $3000 \mathrm{~g}$ for $45 \mathrm{~min}$. The supernatant fluid was then centrifuged at 105,000 $\mathrm{g}$ for $1 \mathrm{hr}$ and the resulting pellet resuspended in TBS. This suspension was treated for 30 sec. in a Raytheon sonic oscillator and clarified by centrifugation at $3000 \mathrm{~g}$ for $30 \mathrm{~min}$. The supernatant fluid was then centrifuged at $105,000 \mathrm{~g}$ for $1 \mathrm{hr}$ and the resulting pellet suspended in TBS. This final suspension, which will be referred to as 'stock virus', was distributed in vials, sealed, frozen on dry ice and stored at $-\mathbf{7 0 ^ { \circ }}$.

Caseinase $C$. Throughout the experiments we used two stocks of purified caseinase C (Ghuysen, Leyh-Bouille \& Dierickx, 1962). The enzyme was dissolved in distilled water and stored at $-70^{\circ}$. One stock solution which contained $1.12 \mathrm{mg}$. protein $/ \mathrm{ml}$., had an enzymic activity of 1000 caseinolytic units/ml.; the other one contained 500 caseinolytic units $/ \mathrm{ml}$. One caseinolytic unit is defined as the amount of enzymic preparation which digests $50 \%$ of the casein present in $0.5 \mathrm{ml}$. of standard solution $\left(0.2 \%, w / v\right.$, soluble casein in $\left.0.05 \mathrm{M}^{-} \mathrm{K}_{2} \mathrm{HPO}_{4}\right)$ within $15 \mathrm{~min}$. when incubated at $3^{\circ}$ (Reginster, 1966).

Enzyme treatment. (i) Treatment in TBS. Stock virus in TBS was thawed and divided into two equal samples. Caseinase $\mathrm{C}$ was added $(50$ units $/ \mathrm{ml}$. when not otherwise stated) to the first one, and a corresponding volume of distilled water to the second one. After incubation at $37^{\circ}$ for $1 \mathrm{hr}$, the two samples were titrated and samples taken for electron microscopy. TBS is a solution of high ionic strength and at $\mathbf{p H ~ 9 \cdot 0 .}$ (ii) Treatment in PB. Frozen or fresh stock virus was centrifuged at $125,000 \mathrm{~g}$ for $1 \mathrm{hr}$. The pellet was resuspended in PB; the solution was divided into two equal portions. Caseinase C (20 to 125 units/ml.) was added to the first one and a corresponding volume of distilled water to the second one. After incubation at $37^{\circ}$ for $30-90 \mathrm{~min}$., the suspensions were titrated and samples taken for electron microscopy. Sometimes, the suspensions were centrifuged after enzyme treatment. $\mathrm{PB}$ is a solution of low ionic strength and at $\mathrm{pH} \mathbf{7 \cdot 0 .}$

Haemagglutination. The technique of Clarke \& Casals (1958), with goose red blood 
cells and plastic trays, was used. One haemagglutinating unit (h.a.u.) is defined as the least quantity of virus giving partial haemagglutination.

Infectivity assay. Petri dishes (diam. $7 \cdot 5 \mathrm{~cm}$.) seeded with 3 to $4 \times 10^{7}$ chick embryo cells suspended in $10 \mathrm{ml}$. growth medium were incubated for $24 \mathrm{hr}$ at $36^{\circ}$ to obtain a monolayer. The growth medium was then discarded and the monolayer washed once with GBSS. Thereafter, the cells were inoculated with $1 \mathrm{ml}$. of serial 10-fold dilutions of viral suspensions and adsorption was allowed for $90 \mathrm{~min}$. at room temperature. The excess of inoculum was sucked off and $7.5 \mathrm{ml}$. agar overlay poured on the cell sheet. The plates were incubated $48 \mathrm{hr}$ at $36^{\circ}$ and then stained with neutral red before counting the plaques.

Infectious-RNA liberation and assay. The virus suspensions were diluted $1 / 2$ in a $4 \%(\mathrm{w} / \mathrm{v})$ solution of sodium deoxycholate in phosphate buffered saline $(\mathrm{pH} \mathbf{7 \cdot 2}$; $0.02 \mathrm{M}$-phosphate $+0.30 \mathrm{M}-\mathrm{NaCl}$ ) and incubated $30 \mathrm{~min}$. at $2^{\circ}$. Controls were diluted in phosphate buffered saline without deoxycholate. Deoxycholate-treated virus and controls were also incubated in presence of ribonuclease $(0 \cdot 6 \mu \mathrm{g} . / \mathrm{ml}$.). The assay of these suspensions was done according to the method of Richter \& Wecker (1963). The deposit of the overlay, the following incubation and the staining were done as described in the preceding paragraph.

Centrifugation experiments. One $\mathrm{ml}$. of the caseinase $\mathrm{C}$ treated suspension and $\mathrm{I} \mathrm{ml}$. of the control were each mixed with $3.75 \mathrm{ml}$. of PB. To stop the destruction of infectivity, $150 \mu \mathrm{l}$. of $5 \mathrm{~m}-\mathrm{NaCl}$ in distilled water and $125 \mu \mathrm{l}$. of a $4 \%(\mathrm{w} / \mathrm{v})$ solution of bovine plasma albumin in distilled water were added to the treated suspension, and similarly to the diluted control. The virus suspensions were then centrifuged in the SW39 rotor of a Spinco preparative centrifuge at $125,000 \mathrm{~g}$ for $1 \mathrm{hr}$. This centrifugation was sufficient to sediment more than $90 \%$ of the virus particles in the controls. After centrifugation, the upper $4.8 \mathrm{ml}$. were set apart and called supernatant fluid. The lower $0 \cdot 2 \mathrm{ml}$., called pellet, was diluted 5 times in phosphate buffered saline ( $\mathrm{pH} 7.2 ; 0.01 \mathrm{~m}$-phosphate $+0.15 \mathrm{M}-\mathrm{NaCl}$ ). The total amount of haemagglutinating units, of virus plaque forming units (p.f.u.) and of deoxycholate liberable infectious RNA plaque-forming units (RNA-p.f.u.) present in the pellet and in the supernatant fluid were determined.

Electron microscopy. A sample of the virus suspension was mixed with an equal volume of potassium phosphotungstate solution $(2 \%, \mathrm{w} / \mathrm{v}$, in distilled water adjusted to $\mathrm{pH} \mathrm{7.0;} \mathrm{Brenner} \mathrm{\&} \mathrm{Horne,} \mathrm{1959).} \mathrm{One} \mathrm{drop} \mathrm{of} \mathrm{the} \mathrm{mixture} \mathrm{was} \mathrm{placed} \mathrm{on} \mathrm{a}$ grid, already coated with Formvar $(0 \cdot 2 \%, \mathrm{w} / \mathrm{v})$ and carbon. After $5 \mathrm{~min}$., the excess of the suspension was blotted away. These preparations were examined with the Siemens Elmiskop 1, direct magnification $\times 40,000$. The dimensions of the particles were measured on the final prints $(\times 120,000)$, the magnification of which was controlled by the latex particles (diam. $126 \mathrm{~m} \mu$ ) present in some preparations. Each one of the given dimensions is the mean of at least 50 measurements, from 4 different sets of experiments. For counting the virus particles a mixture of virus and latex particles (Dow Chemical Co.) was sprayed from a commercial atomizer on the coated grids (Horne, 1961). The suspension to be sprayed was prepared by adding, in equal volumes, the latex suspension $\left(9.2 \times 10^{10}\right.$ particles $/ \mathrm{ml}$.), the phosphotungstate $(1 \%, w / v)$, a solution of bovine plasma albumin $(0.4 \%, w / v$ in 0.005 M-phosphate buffer, $\mathrm{pH} \mathrm{7 \cdot 0)}$ and the virus suspension the concentration of which was always chosen to give 2 to 5 virus particles/latex sphere (Miller \& Ziegler, 1964). 
Two hundred latex spheres and the corresponding number of virus particles were counted from at least 10 droplets of each preparation. The count was made directly on the screen of an Hitachi HS6 electron microscope (magnification $\times 10,000$ ).

\section{RESULTS}

\section{Characteristics of the stock virus}

Haemagglutinating activity, infectivity and particle count. Our stock virus preparations were characterized by haemagglutination titres ranging from $10^{4 \cdot 1}$ to $10^{6 \cdot 6}$ haemagglutinating units (h.a.u.)/ml. and by infectious titres ranging from $10^{9.8}$ to $10^{11.7}$ plaque-forming units (p.f.u.)/ml. Two stock virus preparations were titrated five times. For one of these, $\log _{10}$ haemagglutinating titre was $5 \cdot 9 \pm 0.5$ and $\log _{10}$ infectious titre $11 \cdot 5 \pm 0 \cdot 2$. For the other one, $\log _{10}$ haemagglutinating titre was $5 \cdot 6 \pm 0 \cdot 3$ and $\log _{10}$ infectious titre $10 \cdot 5 \pm 0 \cdot 2$.

The particle count was done on four stock preparations. Table 1 shows that in our experiments one haemagglutinating unit represented $7 \cdot 4 \times 10^{6}$ viral particles and that one plaque-forming unit contained on the average 22 virus particles.

Table 1. Haemagglutinating activity, infectivity and particle count of Semliki Forest virus stock suspensions

\begin{tabular}{cccc} 
& \multicolumn{3}{c}{ Log $_{10}$ number of units $/ \mathrm{ml}}$. \\
\cline { 2 - 4 } Stock no. & Haemagglutinating & Plaque-forming & Physical count \\
18 & $5 \cdot 6$ & $11 \cdot 2$ & $12 \cdot 5$ \\
19 & $5 \cdot 9$ & $11 \cdot 4$ & $12 \cdot 7$ \\
20 & $5 \cdot 9$ & $11 \cdot 3$ & $12 \cdot 7$ \\
21 & $5 \cdot 6$ & $11 \cdot 2$ & $12 \cdot 6$ \\
Mean & $5 \cdot 75$ & $11 \cdot 27$ & $12 \cdot 62$
\end{tabular}

Particle morphology. The images given by the different stock virus suspensions were very homogenous and showed only concentrated virus material (PI. 1, fig. 1, 2); about half of the particles, penetrated by the stain, appeared 'empty'. The shape of the full virus particle was roughly spherical; some particles showed a lateral protrusion which sometimes took a tail-like appearance. The mean overall diameter of the particles was $575 \AA$ (range 550-590). The surface of the particle and of its occasional protrusion was entirely covered with very thin (10-20 $\AA$ ) projections. These projections were regularly spaced on the surface of the particles (centre to centre distance about $50 \AA$ ). They did not seem to design a simple fringe around the particles, but appeared to be connected one with the other at approximately half of their length, giving to the virus the general appearance of a sphere covered with a net. These projections were quite different from the spikes of influenza virus (Pl. 1, fig. 3). The thickness of the ring made by the projections around the particles is of $70 \AA$ (range 50-80), and the mean diameter of the particles measured when the projections were not taken into account was $440 \AA$ (range 410-460). The outer layer, supporting the projections, which was clearly visible on the empty-looking viral structures, was about $30 \AA$ thick. Although the external structure of the virus was clearly the result of the repetition of similar structures, we could not distinguish any characteristic symmetry. Virus suspended in TBS or in PB and incubated at $37^{\circ}$ did not show any modification of their morphology. 


\section{Effects of caseinase $C$ treatment of virus in tris-buffered saline}

Haemagglutinating activity, infectivity and particle count. When the virus stock was treated for $1 \mathrm{hr}$ with caseinase C in TBS the infectivity of the virus suspension was only slightly decreased, but the haemagglutinating activity was almost completely destroyed. The particle count was not significantly modified (Table 2). Decreasing the concentration of caseinase $\mathrm{C}$ to $12 \mathrm{units} / \mathrm{ml}$. or increasing it to 100 units/ml. did not change the \% haemagglutinating activity that was destroyed. But, when the concentration of enzyme was 100 units/ml., the infectivity was then decreased to $30 \%$ of its original value.

Table 2. Haemagglutinating activity, infectivity and particle count of Semliki Forest virus suspensions treated with caseinase $C$ in tris-buffered saline

In all experiments the amount of caseinase $C$ was 50 units $/ \mathrm{ml}$. and incubation was at $87^{\circ}$ for $60 \mathrm{~min}$.

\begin{tabular}{|c|c|c|c|c|c|c|}
\hline \multirow{2}{*}{$\begin{array}{c}\text { Expt. } \\
\text { no. }\end{array}$} & \multicolumn{2}{|c|}{ Haemagglutinating } & \multicolumn{2}{|c|}{ Plaque-forming } & \multicolumn{2}{|c|}{ Physical count } \\
\hline & Control & Treated & Control & Treated & Control & Treated \\
\hline 1 & $6 \cdot 6$ & $2 \cdot 1$ & $11 \cdot 2$ & $11 \cdot 1$ & - & - \\
\hline 2 & $5 \cdot 4$ & $2 \cdot 4$ & $11 \cdot 5$ & $11 \cdot 3$ & - & - \\
\hline $\mathbf{3}$ & $6 \cdot 0$ & $2 \cdot 7$ & $11 \cdot 4$ & $10 \cdot 9$ & - & - \\
\hline 4 & $5 \cdot 9$ & $\mathbf{3 \cdot 2}$ & $11 \cdot 2$ & $11 \cdot 2$ & $12 \cdot 8$ & $12 \cdot 8$ \\
\hline 5 & $\mathbf{5 \cdot 9}$ & $\mathbf{2 \cdot 9}$ & $11 \cdot 3$ & $11 \cdot 2$ & $12 \cdot 7$ & $12 \cdot 7$ \\
\hline 6 & $\mathbf{5 \cdot 9}$ & $\mathbf{2 \cdot 6}$ & $11 \cdot 4$ & $11 \cdot 3$ & $12 \cdot 6$ & $12 \cdot 3$ \\
\hline Mean & $5 \cdot 9$ & $\mathbf{2 \cdot 6}$ & $11 \cdot 3$ & $11 \cdot 2$ & $12 \cdot 7$ & $12 \cdot 5$ \\
\hline
\end{tabular}

Particle morphology. Electron micrographs of the treated virus showed that the projections had disappeared (Pl. 1, fig. 4). The remaining structures had an average diameter of $435 \AA$ (range 410-450), almost equal to the diameter of the untreated particles measured without taking the projections into account. Empty particles were still present in the preparations. On the micrographs, the tail-like protrusions are clearly shown to consist of a fold of the outer layer (Pl. 1, fig. 4, 5). This deformable layer will be, from now on, called envelope. As the envelope has the same thickness on the micrographs of control virus and of treated virus, it seems unlikely that the projections were merely flattened down by the treatment. They must have been removed or at least sufficiently modified as to become too thin to be seen in negatively-stained preparations. When the concentration of caseinase $\mathbf{C}$ was less than 25 units $/ \mathrm{ml}$. the projections were only partly removed, although the haemagglutinating activity was destroyed. When the concentration of enzyme was 100 units/ml. some of the virus particles showed incipient degradation of the envelope. Under the experimental conditions chosen, it can be concluded that caseinase $\mathrm{C}$ (50 units/ml.) does not modify the infectivity of Semliki Forest virus suspensions and does not decrease the number of virus particles. However, it destroys the haemagglutinating activity and removes or modifies the projections which normally cover the virus particle. 


\section{Caseinase $C$ treatment of virus in phosphate buffer}

Haemagglutinating activity, infectivity and particle count. Experiments in PB confirmed that the haemagglutinating activity was much more sensitive to caseinase $\mathrm{C}$ than was the infectivity. Table $\mathbf{3}$ shows that although in all our experiments about $99.9 \%$ of the haemagglutinating activity was destroyed, the destruction of infectivity was irregular. The destruction of infectivity was more pronounced when the enzyme concentration and the incubation time were increased and when the initial infectious titre of the viral suspension was relatively low. The virus particles were counted in four experiments. The total number of virus particles was not much modified, although the infectious titre was decreased by the caseinase $\mathbf{C}$ treatment to less than about $10 \%$ of its original value.

Table 3. Haemagglutinating activity, infectivity and particle count of Semliki Forest virus suspensions treated with caseinase $C$ in phosphate buffer

All incubations were at $37^{\circ}$.

\begin{tabular}{|c|c|c|c|c|c|c|c|c|}
\hline \multirow{3}{*}{$\begin{array}{c}\text { Expt. } \\
\text { no. }\end{array}$} & \multirow{3}{*}{$\begin{array}{c}\text { Amount } \\
\text { of } \\
\text { caseinase C } \\
\text { (units/ml.) }\end{array}$} & \multirow{3}{*}{$\begin{array}{c}\text { Time of } \\
\text { incubation } \\
\text { (min.) }\end{array}$} & \multicolumn{6}{|c|}{$\log _{10}$ number of units/ml. } \\
\hline & & & \multicolumn{2}{|c|}{ Haemagglutinating } & \multicolumn{2}{|c|}{ Plaque-forming } & \multicolumn{2}{|c|}{ Physical count } \\
\hline & & & Control & Treated & Control & Treated & Control & Treated \\
\hline 1 & 20 & $\mathbf{3 0}$ & $5 \cdot 6$ & $\mathbf{3 \cdot 2}$ & $11 \cdot 0$ & $10 \cdot 9$ & 一 & - \\
\hline 2 & 20 & 30 & $4 \cdot 4$ & $\mathbf{2 \cdot 0}$ & $\mathbf{9 \cdot 9}$ & $\mathbf{9 \cdot 3}$ & - & - \\
\hline $\mathbf{3}$ & 25 & 30 & $4 \cdot 9$ & $1 \cdot 3$ & $9 \cdot 7$ & $8 \cdot 7$ & - & 一 \\
\hline 4 & 25 & 30 & $\mathbf{3 \cdot 4}$ & 0.7 & $\mathbf{9 \cdot 3}$ & $6 \cdot 9$ & - & - \\
\hline 5 & 25 & 60 & $5 \cdot 0$ & $2 \cdot 6$ & $10 \cdot 2$ & $9 \cdot 0$ & $12 \cdot 1$ & $11 \cdot 9$ \\
\hline 6 & 25 & 60 & $5 \cdot 8$ & 2.5 & $10 \cdot 2$ & $7 \cdot 0$ & - & - \\
\hline 7 & 25 & 90 & $5 \cdot 9$ & $2 \cdot 9$ & $10 \cdot 8$ & 9.5 & $12 \cdot 6$ & $12 \cdot 5$ \\
\hline 8 & 25 & 80 & $\mathbf{5} \cdot \mathbf{3}$ & $\mathbf{2 \cdot 9}$ & $10 \cdot 9$ & $\mathbf{8} \cdot \mathbf{3}$ & $12 \cdot 5$ & $12 \cdot 3$ \\
\hline 9 & $\mathbf{3 0}$ & $\mathbf{3 0}$ & $5 \cdot 6$ & $\mathbf{2 \cdot 0}$ & $10 \cdot 7$ & $10 \cdot 6$ & - & - \\
\hline 10 & $\mathbf{3 0}$ & 30 & $4 \cdot 4$ & $\mathbf{2 \cdot 0}$ & $\mathbf{9} \cdot 8$ & $8 \cdot 7$ & - & - \\
\hline 11 & $\mathbf{3 0}$ & 90 & $4 \cdot 6$ & $1 \cdot 6$ & $\mathbf{9 \cdot 9}$ & $5 \cdot 7$ & 一 & - \\
\hline 12 & $\mathbf{5 0}$ & 60 & $5 \cdot 0$ & $\mathbf{2 \cdot 6}$ & $10 \cdot 2$ & $7 \cdot 3$ & $12 \cdot 1$ & $11 \cdot 7$ \\
\hline
\end{tabular}

In one experiment we incubated at $37^{\circ}$ for $60 \mathrm{~min}$. samples of the virus suspension to which were added increasing amounts of enzyme (Fig. 1). The haemagglutinating titre was decreased to less than $1 \%$ of its original value. This destruction was not increased by higher enzyme concentrations. The infectivity was decreased, and the degree of destruction was proportional to the enzyme concentration. The total number of particles was decreased to about $50 \%$ of the original value. The treated preparations did not show empty particles. Thus, the decrease in number of particles was very likely the result of the destruction of these empty particles. The treated particles showed some tendency to form aggregates containing various numbers of particles. The total decrease in number of infectious units, counting an aggregate as an infectious unit, is represented by the curve VPa of Fig. 1. It is clear that if each aggregate of several particles behaved as an isolated virus infectious unit during the infectivity assay, the decrease in number of infectious units resulting from aggregation would not account for the loss of infectivity.

Particle morphology. The images obtained with treated preparations which showed 
no decrease of infectivity were similar to those obtained from the virus treated with caseinase $\mathrm{C}$ in TBS. When the infectivity of the virus was destroyed by this treatment, the resulting particles appeared to be without projections and their envelope showed various degrees of alteration (Pl. 2). Sometimes pieces of envelope were seen isolated or in the process of being stripped off (Pl. 2, fig. 8). Some particles were devoid of envelope. Their mean diameter was $390 \AA$ (range 385-395) and their surface did not show any morphological details. These naked particles will be called cores. Some debris were also visible on the micrographs in the form of hollow polygonal structures about $120 \AA$ wide (Pl. 2, fig. 7).

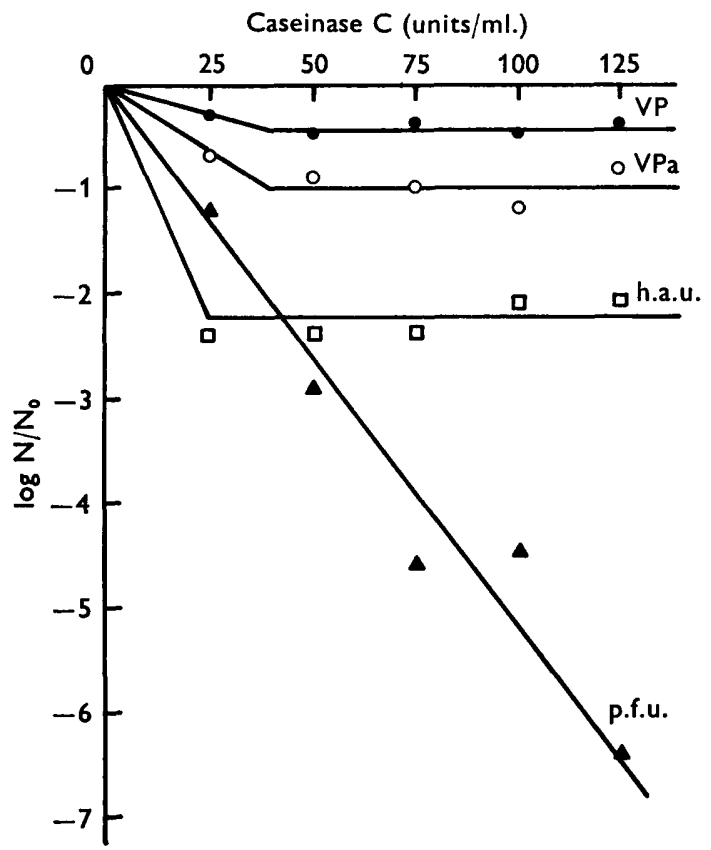

Fig. 1. Haemagglutinating activity, infectivity and particle count of Semliki Forest virus suspensions treated with various doses of caseinase $C$ in phosphate buffer. $N$ : number of plaque-forming units (p.f.u.)/ml. after treatment (or h.a.u. or VP or VPa). $\mathbf{N}_{0}$ : number of p.f.u./ml. before treatment (or h.a.u. or VP or VPa). VP: virus particles. VPa: virus particle agglomerations. Incubation was at $37^{\circ}$ for $1 \mathrm{hr}$.

\section{Centrifugation experiments}

As the loss of infectivity could not be accounted for either by an aggregation of the particles or by a decrease of their total number, we looked for a release by the enzyme of infectious RNA or for a modification of the RNA infectivity. The caseinase $C$-treated and control viral suspensions of experiments 9, 10 and 11 (Table 3 ) were centrifuged at $125,000 \mathrm{~g}$ for $1 \mathrm{hr}$. Table 4 gives the distribution between supernatant fluids and pellets of the values of h.a.u., p.f.u. and RNAp.f.u. (obtained after deoxycholate treatment). In control as well as in treated suspensions, the infectivity and the deoxycholate-liberated RNA infectivity sedimented likewise, $90 \%$ being in the pellet. In controls, $90 \%$ of the haemagglutinating activity was also collected in the pellet, but far less of the residual haemag- 
glutinating activity sedimented from the suspensions treated with caseinase $\mathrm{C}$. Small haemagglutinating structures were released by this treatment but there was no indication of infectious RNA release.

Table 4. Distribution of total haemagglutinating activity, infectivity and infectivity due to RNA liberated by deoxycholate between supernatant fuids and pellets of centrifuged Semliki Forest virus suspensions after treatment with caseinase $C$ in phosphate buffer (Table 3)

\begin{tabular}{|c|c|c|c|c|c|c|c|}
\hline \multirow{2}{*}{$\begin{array}{l}\text { No. of } \\
\text { expt. in } \\
\text { Tabel } 3\end{array}$} & \multirow[b]{2}{*}{$\begin{array}{c}\text { Viral } \\
\text { suspension }\end{array}$} & \multicolumn{2}{|c|}{$\begin{array}{c}\text { Haemagglutinating } \\
\text { units } \% \text { in }\end{array}$} & \multicolumn{2}{|c|}{$\begin{array}{l}\text { Plaque-forming } \\
\text { units } \% \text { in }\end{array}$} & \multicolumn{2}{|c|}{$\begin{array}{l}\text { RNA plaque-forming } \\
\text { units } \% \text { in }\end{array}$} \\
\hline & & $\begin{array}{c}\text { Super- } \\
\text { natant fluid }\end{array}$ & Pellet & $\begin{array}{l}\text { Super- } \\
\text { natant fluid }\end{array}$ & Pellet & $\begin{array}{c}\text { Super- } \\
\text { natant fluid }\end{array}$ & Pellet \\
\hline 9 & $\begin{array}{l}\text { Control } \\
\text { Treated }\end{array}$ & $\begin{array}{r}4 \\
18\end{array}$ & $\begin{array}{l}96 \\
82\end{array}$ & $\begin{array}{r}2 \\
10\end{array}$ & $\begin{array}{l}98 \\
90\end{array}$ & $\begin{array}{l}\mathbf{3} \\
\mathbf{9}\end{array}$ & $\begin{array}{l}97 \\
91\end{array}$ \\
\hline 10 & $\begin{array}{l}\text { Control } \\
\text { Treated }\end{array}$ & $\begin{array}{r}13 \\
>35\end{array}$ & $\begin{array}{r}87 \\
<65\end{array}$ & $\begin{array}{r}9 \\
14\end{array}$ & $\begin{array}{l}91 \\
86\end{array}$ & $\begin{array}{l}10 \\
12\end{array}$ & $\begin{array}{l}90 \\
88\end{array}$ \\
\hline 11 & $\begin{array}{l}\text { Control } \\
\text { Treated }\end{array}$ & $\begin{array}{l}16 \\
25\end{array}$ & $\begin{array}{l}84 \\
75\end{array}$ & $\begin{array}{r}\mathbf{3} \\
\geqslant \mathbf{3}\end{array}$ & $\begin{array}{r}97 \\
\leqslant 97\end{array}$ & $\begin{array}{l}1 \\
7\end{array}$ & $\begin{array}{l}99 \\
93\end{array}$ \\
\hline
\end{tabular}

Table 5. Ratios of the virus infectious titre to the deoxycholate-liberated RNA infectious titre of Semliki Forest virus suspensions treated with caseinase $C$ in phosphate buffer

The suspensions were centrifuged at $125,000 \mathrm{~g}$ for $60 \mathrm{~min}$.

\begin{tabular}{|c|c|c|c|c|}
\hline \multirow[b]{2}{*}{$\begin{array}{l}\text { No. of } \\
\text { expt. in } \\
\text { Table } 3\end{array}$} & \multirow[b]{2}{*}{$\begin{array}{c}\text { Viral } \\
\text { suspension }\end{array}$} & \multicolumn{3}{|c|}{$\log _{10}$ ratios of infectious titres of } \\
\hline & & $\begin{array}{c}\text { Treated virus: } \\
\text { RNA of treated } \\
\text { virus }\end{array}$ & $\begin{array}{c}\text { Control virus: } \\
\text { RNA of control } \\
\text { virus }\end{array}$ & $\begin{array}{c}\text { Control virus: } \\
\text { RNA of treated } \\
\text { virus }\end{array}$ \\
\hline 11 & $\begin{array}{l}\text { Supernatant } \\
\text { Pellet } \\
\text { Original }\end{array}$ & $\begin{array}{l}0 \cdot 1 \\
0 \cdot 2 \\
0 \cdot 3\end{array}$ & $\begin{array}{l}4 \cdot 7 \\
4 \cdot 3 \\
4 \cdot 7\end{array}$ & $\begin{array}{l}4 \cdot 7 \\
5 \cdot 2 \\
4 \cdot 4\end{array}$ \\
\hline 10 & $\begin{array}{l}\text { Pellet } \\
\text { Supernatant }\end{array}$ & $\begin{array}{l}\mathbf{3} \cdot \mathbf{1} \\
\mathbf{3} \cdot \mathbf{3}\end{array}$ & $\begin{array}{l}4 \cdot 0 \\
4 \cdot 0\end{array}$ & $\begin{array}{l}4 \cdot 9 \\
4 \cdot 8\end{array}$ \\
\hline $\boldsymbol{9}$ & $\begin{array}{l}\text { Original } \\
\text { Supernatant } \\
\text { Pellet }\end{array}$ & $\begin{array}{c}4 \cdot 1 \\
4 \cdot 2 \\
4 \cdot 2 \\
\text { Mean }\end{array}$ & $\begin{array}{c}4 \cdot 0 \\
4 \cdot 4 \\
4 \cdot 3 \\
4 \cdot 3 \pm 0 \cdot 3\end{array}$ & $\begin{array}{c}4 \cdot 2 \\
4 \cdot 7 \\
4 \cdot 0 \\
4 \cdot 6 \pm 0 \cdot 4\end{array}$ \\
\hline
\end{tabular}

Samples of uncentrifuged suspensions, supernatant fluids and pellets were treated with sodium deoxycholate to liberate the infectious RNA which was then titrated. Ribonuclease tests, not included into the Tables, proved that the infectivity measured was destroyed by this enzyme and that infectious RNA did not interfere with the virus plaque-forming-units assay. Almost all the virus infectivity was destroyed by the deoxycholate treatment (Richter \& Wecker, 1963; Osterrieth, 1964). When the caseinase $C$ treatment destroyed a significant proportion of the infectivity, the p.f.u.:RNA-p.f.u. ratio was far greater in control than in treated suspensions (Table 5). The discrepancy between the p.f.u.:RNA-p.f.u. ratios of control and treated suspensions decreased together with the destruction of infectivity. When the infectivity had not been destroyed by the caseinase $\mathrm{C}$ treatment, the p.f.u.: RNA-p.f.u. ratio was similar in control and treated suspensions (expt. no. 9, 
Table 3). In view of these differences, we also compared the virus infectious titre of the controls with the infectious RNA titre of the treated suspensions (Table 5, last column). These ratios were not significantly different from the p.f.u.:RNA-p.f.u. ratios of the controls.

Since in each experiment the ratios p.f.u.:RNA-p.f.u. of the treated suspensions were similar in supernatant fluids and pellets, we have an indication that the infectious RNA is not liberated by caseinase $\mathrm{C}$ treatment. Additional evidence is given by the fact that the ratios p.f.u. of controls: RNA-p.f.u. of caseinase $C$ treated are similar to the ratios p.f.u. control:RNA-p.f.u. control. This observation also shows that the infectivity of the infectious RNA was not modified by treatment with caseinase $\mathbf{C}$.

Thus when Semliki Forest virus was treated with a sufficient amount of caseinase $\mathrm{C}$ in PB, the haemagglutinating activity and the infectivity were both destroyed, the surface projections disappeared, and the envelope was degraded and eventually destroyed. After such treatment there was no proportionality between the particle count, the particle aggregation and the virus infectious titre. The infectious RNA was neither released nor inactivated.

\section{DISCUSSION}

Negatively-stained Semliki Forest virus appears to be formed of a roughly spherical core surrounded by a loose envelope which bears very thin projections. We cannot tell whether the nucleic acid within the core is free or protein-bound RNA, because the infectious RNA was liberated by deoxycholate treatment. The cores might be similar to the intracellular immature virus particles described by Mussgay \& Weibel (1962) and Morgan, Howe \& Ross (1961). They might also be related to the ribonucleoprotein extracted from infected cells (Wecker \& Richter, 1962; Wecker \& Schonne, 1961). Comparable cores have been described for Venezuelan equine encephalitis virus (Klimenko et al. 1965). Since we did not observe any structural details of the surface of the envelope nor of the core, we cannot give the name of capsid to any of the observed structures.

The projections and the envelope are sensitive to the action of caseinase $C$. Since we could not find any evidence for a liberation of RNA, we think that the cores are not sensitive to caseinase $\mathrm{C}$ in our experimental conditions.

Whether the projections are cut off, digested or only modified remains a matter for discussion, but they appear to harbour at least one site which is sensitive to caseinase $\mathbf{C}$ action. They are much more readily attacked by caseinase $\mathrm{C}$ than is the envelope which shows signs of enzymic disruption only when the enzymic treatment is done in phosphate buffer PB.

The haemagglutinating activity, similarly, is easily destroyed by caseinase $\mathrm{C}$, but the destruction of infectivity requires the conditions which are necessary for envelope disruption. Haemagglutinating activity is also more readily destroyed by Pronase (Osterrieth, 1965a) than is infectivity. This is unusual; generally chemical destruction of the haemagglutinating activity also destroys the infectivity, e.g. the action of sulphydryl reagents on enteroviruses (Philippson \& Choppin, 1961) and of proteases on group $B$ arboviruses (Cheng, 1958).

The presence (or integrity) of the projections was not a pre-requisite for infec- 
tivity. Since the projections and the haemagglutinating activity always disappeared together, although the latter more rapidly, it is reasonable to infer that the projections carry the site for haemagglutination. Tween + ether disruption of Sindbis virus, which disrupts the envelope without apparent modification of the projections, points out to the same localization of the haemagglutinating sites (Mussgay \& Rott, 1964).

Mild caseinase $\mathrm{C}$ treatment done in phosphate buffer leads to the disappearance of the projections and of the haemagglutinating activity. Increasing caseinase $\mathrm{C}$ concentration or the time of the incubation brings a disruption of the envelope as well as destruction of the infectivity. Since neither a liberation of the RNA nor a decrease of its infectivity could be found, and as neither a decrease in number nor an aggregation of the virus particles could be held responsible for the loss of infectivity, we believe that the latter is the result of envelope disruption. Accordingly, the site for haemagglutination is different from the site for infectivity. Ether disruption of Murray Valley encephalitis virus also liberates from the virus a noninfectious structure which contains the RNA but which is not ribonuclease sensitive (Anderson \& Ada, 1961). Smith (1964) suggested that the envelope of herpes virus may be necessary for its infectivity but Watson, Wildy \& Russell (1964) suggested the opposite.

We define the envelope as the deformable outer layer of Semliki Forest virus which bears the projections and which can be destroyed by caseinase $C$. The viral envelope is described as the lipoprotein-containing outer layer of lipid-containing viruses, and it is supposed to be formed by some budding process through the host-cell membrane during the release of virus (Franklin, 1962; Knight, 1963; Mussgay, 1964). Lipases destroy the infectivity of arboviruses (Takehara \& Hotta, 1961), and these are sensitive to ether (Andrewes \& Horstman, 1949) and to deoxycholate (Theiler, 1957). It seems that any treatment, either proteolytic or lipolytic, which degrades to a certain extent the envelope of arboviruses, even if it does not disrupt the particle, destroys the infectivity. The importance of the envelope for the infectivity of Semliki Forest virus, and probably for arboviruses in general, is in agreement with the hypothesis which Cohen (1963) offered to explain the first steps of the infection of cells by myxoviruses: ' On close apposition of the virus cell surface, there is a fusion of the opposing lipoprotein membranes with establishment of continuity. In this way, the virus membrane envelope becomes incorporated in the cell membrane and the internal constituent of the virus becomes extruded in the cytoplasm.' The process of penetration into the cell is perhaps similar for arboviruses and myxoviruses, since these viruses share some common features. Both types of viruses are enveloped and covered with projections which are probably the site for haemagglutination, both are ether sensitive, both contain RNA. In phosphate buffer, caseinase $\mathrm{C}$ treatment destroyed the infectivity and the haemagglutinating activity of Semliki Forest virus and of influenza virus(Reginster, $1965 a, b$; Osterrieth, $1965 a$ ). Nevertheless, significant differences exist. The infectivity of influenza virus is more sensitive to caseinase $\mathrm{C}$ than is its haemagglutinating activity, whereas the reverse holds for Semliki Forest virus. The projections of these two viruses are morphologically different. The envelope of influenza virus is twice as thick (70-100 $\AA$; Horne $\&$ Wildy, 1963) as that of Semliki Forest virus, and is not disrupted by a caseinase $C$ treatment in phosphate 
buffer which degrades the envelope of Semliki Forest virus. If the two viruses certainly share some chemical components in their outer layer, these appear to be located in different structures.

We express our gratitude to Professor A. Claude and Dr E. Mrena for their help and advice, and to Professor M. Florkin for the use of the electron microscope. We acknowledge the technical aid of Mrs Heusden, Miss Hansen, Mr Renson, Mr Mommens and Mr Gerard, and we thank the Dow Chemical Company for providing the latex spheres suspension.

P.M.O. was a 'Chercheur Qualifié' and C.M.C.B. a 'Chargé de Recherches' of the Fonds National de la Recherche Scientifique de Belgique during this work.

\section{REFERENCES}

Anderson, S. G. \& Ada, G. L. (1961). The action of phospholipase A and lipid solvents on Murray Valley encephalitis virus. J. gen. Microbiol. 25, 451.

Andrewes, C. H. \& Horstman, D. H. (1949). The susceptibility of viruses to ethyl ether. J. gen. Microbiol. 3, 290.

BoreCKy, L., LaCKovic, V. \& Mrena, E. (1964). The effect of trypsin on influenza virus. Acta Virol. 8, 555.

Brenner, S. \& Horne, R. W. (1959). A negative staining method for high resolution electron microscopy of viruses. Biochim. biophys. Acta, 34, 103.

Cheng, P. Y. (1958). The inactivation of group B arthropod borne viruses by proteases. Virology, 6, 129.

Cheng, P. Y. (1961). Purification, size and morphology of a mosquito borne animal virus, Semliki Forest virus. Virology, 14, 124.

Clarke, D. \& Casals, J. (1958). Techniques for haemagglutination and haemagglutination inhibition with arthropod borne viruses. Am. J. trop. Med. Hyg. 7, 561.

CoHEN, A. (1963). Mechanism of cell infection. 1. Virus attachment and penetration; in Mechanism of virus infection, p. 153, ed. by Wilson Smith; London, New York: Academic Press.

Frankun, R. M. (1962). The significance of lipids in animal viruses. Progress Med. Virol. $4,1$.

Ghuysen, J. M., Lexh-Bouille, M. \& Dierickx, L. (1962). Structure de la paroi de Bacillus megaterium Kм 1. Isolement de l'amidase et d'un enzyme nouveau secrété par le Streptomyces albus $\mathrm{g}$ et actif sur la parois de Bacillus megaterium et de Micrococcus lysodeikticus. Biochim. biophys. Acta, 63, 286.

HonNe, R. W. (1961). The examination of small particles. In Techniques for electron microscopy. Ed. by D. Kay, p. 150. Oxford: Blackwell Scientific Publications.

Horne, R. W. \& Wildy, P. (1963). Virus structure revealed by negative staining. Advanc. Virus Res. 10, 101.

Klimenko, S. M., Yershov, F. I., Gofman, Y. P., Nabatnikov, A. P. \& Zhdanov, V. M. (1965). Architecture of Venezuelan Equine encephalitis virus. Virology, 27, 125.

Knight, C. A. (1963). Chemistry of viruses. In Protoplasmologia: Handbuch der Protoplasmaforschung. Vienna: Springer Verlag.

Miluer, G. L. \& Ziegler, R. W. (1964). Virus particle count with the negative staining spray droplet technique. Proc. Soc. exp. Biol. Med. 115, 289.

Morgan, C., Howe, C. \& Ross, H. N. (1961). Structure of viruses as observed in the electron microscope. V. Western equine encephalitis virus. J. exp. Med. 113, 219.

Mussgay, M. (1964). Growth cycle of Arboviruses in vertebrates and arthropod cells. Progress Med. Virol. 6, 193.

Mussgay, M. \& RotT, R. (1964). Studies on the structure of an haemagglutinating component of a group A arbovirus (Sindbis). Virology, 23, 573.

Mussgay, M. \& Weibel, J. (1962). Electron microscopic and biological studies on the growth of Venezuelan equine encephalitis virus in KB cells. Virology, 16, 52. 
Osterrieth, P. M. (1964). RNA-like infectious principle liberated from Semliki Forest virus by sodium deoxycholate. Acta Virol. 7, 477.

Osternietr, P. M. (1965a). Comparison of the effect of caseinase $\mathrm{C}$ and Pronase on the haemagglutinating activity and on the infectivity of Semliki Forest virus. Acta Virol. 9, 471.

Osterrieth, P. M. (1965b). Semliki Forest virus inactivation. Selective destruction of the haemagglutinating activity by caseinase $\mathrm{C}$ and of infectivity by sodium deoxycholate. Life Sci. 4, 1227.

Osterrieth, P. M. \& Dierickx, L. (1965). Antiviral activity of an enzyme complex from Streptomyces albus o culture filtrate. Acta Virol. 9, 248.

Philippson, L. \& Choppin, P. W. (1961). On the role of virus sulfhydryl groups in the attachment of enteroviruses to erythrocytes. J. exp. Med. 112, 455.

Porterfield, J. S. (1960). A simple plaque inhibition test for the study of arthropod borne viruses. Bull. Wld Hlth Org. 22, 373.

REGINSTER, M. (1965a). Inactivation of influenza virus by caseinase C from Streptomyces albus G culture filtrate. J. gen. Microbiol. 40, 157.

Reginster, M. (1965b). Modification of influenza virus by Streptomyces albus g caseinase C. Acta Virol. 9, 462.

Reginster, M. (1966). Release of influenza virus neuraminidase by caseinase $\mathrm{C}$ of Streptomyces albus G. J. gen. Microbiol. 42, 323.

Richter, A. \& Wecker, E. (1963). The reaction of Eastern equine encephalitis virus preparation with sodium deoxycholate. Virology, 20, 263.

Smith, K. O. (1964). Relationship between the envelope and infectivity of Herpes virus. Proc. Soc. exp. Biol. Med. 115, 814.

TAkehara, M. \& Hotta, S. (1961). Effect of enzymes on a partially purified Japanese B encephalitis virus and on related arboviruses. Science, 134, 1878.

Theiler, M. (1957). Action of Na desoxycholate on arboviruses. Proc. Soc. exp. Biol. Med. 96, 380.

Watson, D. H., Wildy, P. \& Russell, W. C. (1964). Quantitative electron microscope studies on the growth of Herpes virus using the techniques of negative staining and ultramicrotomy. Virology, 24, 523.

WECKER, E. \& RICHTER, A. (1962). Conditions for the replication of infectious viral RNA. Cold Spr. Harb. Symp. quant. Biol. 27, 137.

WECKER, E., \& SchonNe E. (1961). Inhibition of viral RNA synthesis by parafluorophenylalanine. Proc. natn. Acad. Sci. U.S.A. 47, 278.

\section{EXPLANATION OF PLATES}

Negatively stained preparations of Semliki Forest virus: magnification $\times 180,000$.

Plate 1

Figs. 1-3. Untreated Semliki Forest virus particles (Figs. 1, 2) compared with influenza virus, (Fig. 3).

Figs. 4, 5. Semliki Forest virus particles treated with caseinase $\mathbf{C}$ in tris-buffered saline. The projections are removed (Fig. 4) and the appendix is shown to be formed by a fold of the envelope (Fig. 5).

\section{Plate 2}

Figs. 6-8. Semliki Forest virus particles treated by caseinase $\mathrm{C}$ in phosphate buffer: the envelope is severely damaged (Figs. 6-8). 
Journal of General Microbiology, Vol. 43, No. I

Plate 1
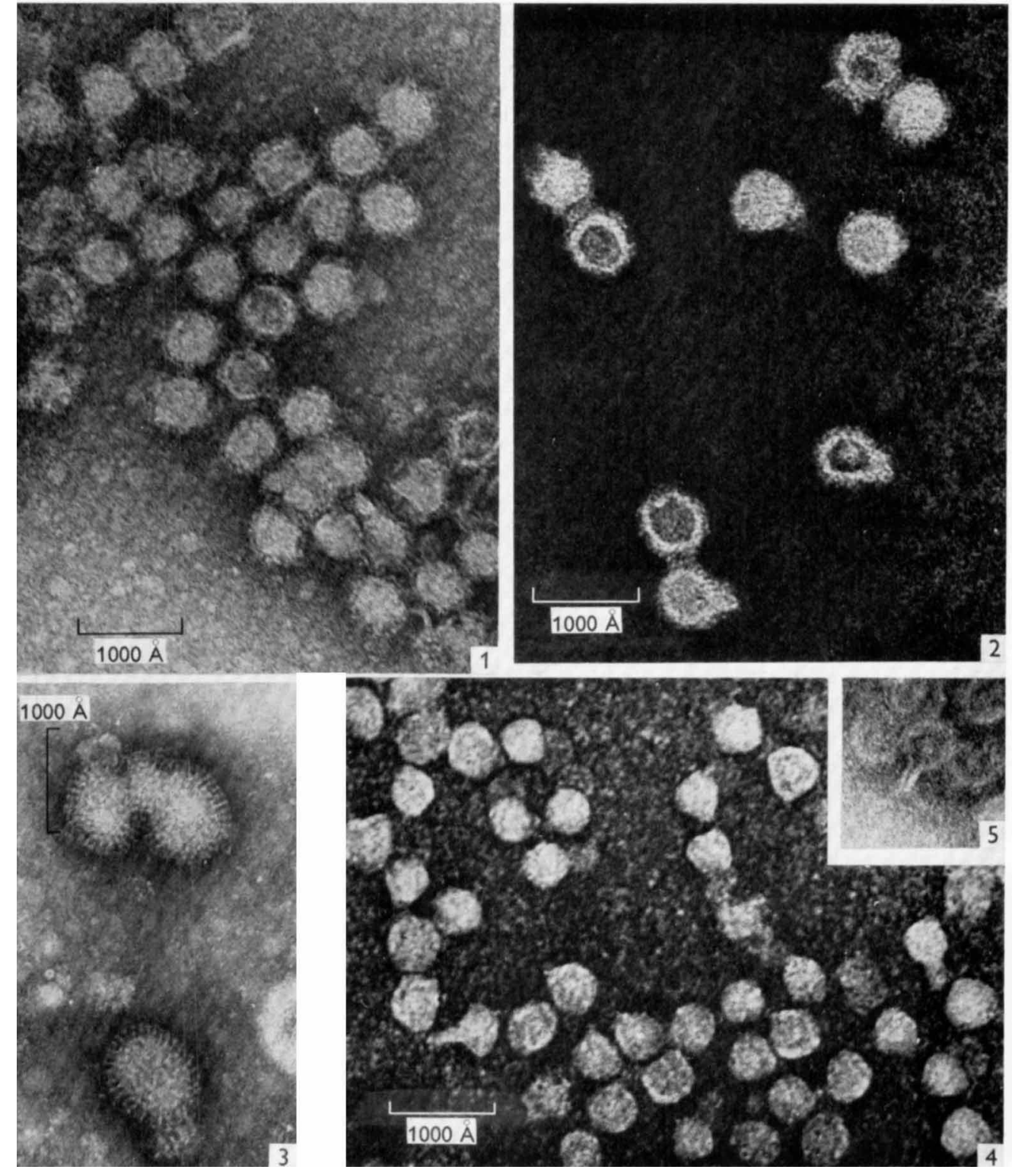

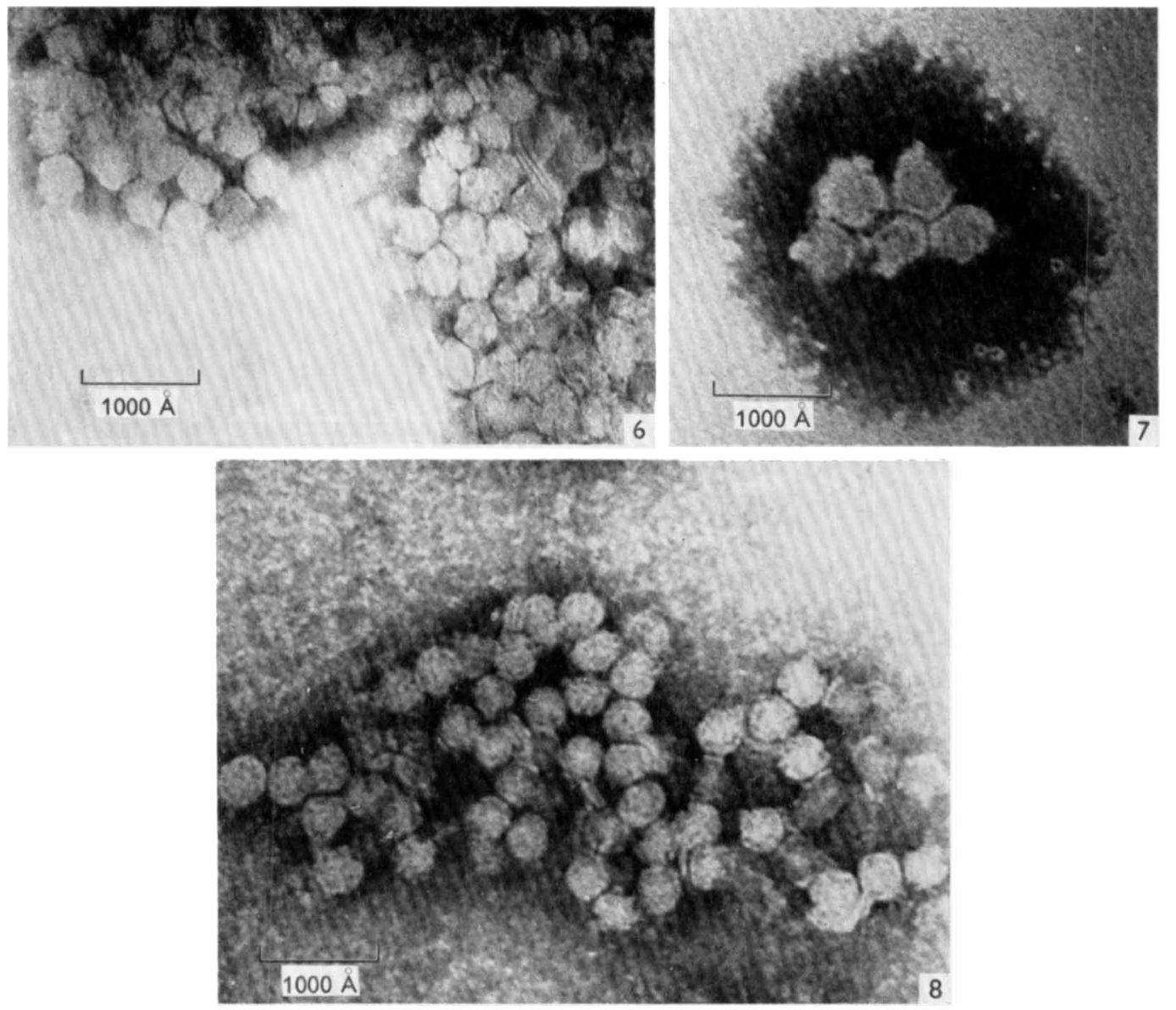

P. M. OSTERRIETH AND C. M. CALBERG-BACQ 